\title{
SOME ENGINEERING FACTORS AFFECTING DATE PITS CRUSHING
}

\author{
Khairy, M. F. A. *; S. H. Desoky**; R. A. Werby**; K. A. M. Ali***
}

\begin{abstract}
The main objective of the present work was to study and evaluate some engineering factors affecting date pits crushing for small locally made crushing unit at moisture content of $7.75 \% \mathrm{db}$. The performance of date pits crushing unit was evaluated at different cylinders speeds (150, 250, 350 and $450 \mathrm{rpm}$ ), clearances between cylinders (zero, 1 and $2 \mathrm{~mm}$ ) and opening feed areas $\left(30,37.5\right.$ and $\left.45 \mathrm{~cm}^{2}\right)$. The results showed that the highest productivity was $822 \mathrm{~kg} / \mathrm{h}$ obtained at $150 \mathrm{rpm}$ cylinder speed, 2 mm clearance between cylinders and $45 \mathrm{~cm}^{2}$ opening feed area. The best result for crushed date pits particle size was obtained at $350 \mathrm{rpm}, 0 \mathrm{~mm}$ clearance between cylinders and $37.5 \mathrm{~cm}^{2}$ opening feed area. While the minimum specific energy $1.11 \mathrm{~kW} . \mathrm{h} / \mathrm{Mg}$ was obtained at $150 \mathrm{rpm}, 45 \mathrm{~cm}^{2}$ opening feed area and $2 \mathrm{~mm}$ clearance between cylinders.
\end{abstract}

\section{INTRODUCTION}

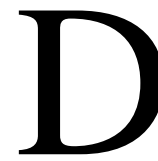
ate palm trees are grown all-over Egyptian lands. In addition, date palm trees considered as the most successful fruit tree that cultivated in the new reclaimed lands in Toshki, El-Ewinates, and Sinai areas (Bekheet, 2013). Egypt is considered as one of the most important producers of date in the whole world. It produce about $1.47 \mathrm{Tg}$ on 2012 (FAO, 2012). There are many by-products from palm trees some of them, date pits (that represents $10-15 \%$ of the date fruit), palm tree leaves, and non-edible dates could be used in animal feeds. The date pits is composed of both organic and inorganic substances such as carbohydrates $62.51 \%$, fats $8.49 \%$, proteins $5.22 \%$, fibers $16.20 \%$, and ash $1.12 \%$ (El-Agamy et al, 2003).

\footnotetext{
*Prof. Emt. of Agri. power and mach. Eng. Dept., Fac. of Agri. Eng., Al-Azhar U. **Assoc. prof. of Agri. power and mach. Eng. Dept., Fac. of Agri. Eng., Al-Azhar U. ***Demons. of Agri. power and mach. Eng. Dept., Fac. of Agri. Eng.,. Al-Azhar U. This study is a part of outcomes from Ali (MSc thesis)
} 
Almana and Mahmaud (1994) evaluated date pits as an alternative source of dietary fiber in comparison with wheat bran, and suggested that they may provide a valuable contribution to dietary fiber intakes. Therefore, date pits were examined because they may have an extractable high value-added component for including in functional foods. Allam et al. (1997) mentioned that Date pits (date stone) by-product meals have been examined in livestock (poultry, and ruminants), and fish (for aquaculture) diets as a nonconventional source to substitute or supplements for expensive conventional feed, and to cut-down on the feed gap between production and consumption. Date stone by-product meal provides a good potential as concentrated feed source for poultry, ruminants and fish feeding instead of maize or other grains that are used for human foods.

Khairy and Attalla (1995) studied physical and mechanical properties of twelve date palm cultivars commonly growing in Gassim region. 50 date fruit were examined for each cultivar. The shapes of these cultivars were studied in terms of fruit length "L", maximum width "A", minimum width "B", pulp thickness "T", pit length "L1", maximum width "A1", minimum width "B1", the angle of friction between date fruit and both of wood "Фw" and galvanized mild steel "Фs" surfaces were measured by inclination-plate method. Pit separation force "PF" $(\mathrm{N})$ and pulp rigidity "RG" (MPa) were measured by an apparatus developed, constructed and calibrated by first author.

Maynard and Heid (1964) and Kozmin (1988) classified the types of milling equipment according to the principles of action of their working organs upon the treated product as follow:

1. Cutting (chipping off) machines.

2. Pressing (crushing) machines.

3. Machine acting by free impact.

Milling equipment may depend upon a single one of these actions or upon a combination of two or more. Miller also can be designed and frequently are to produce attrition and impact grinding. Simmons (1963) and Kozemin (1988) showed that grinders may be placed in two categories:

1. Stone grinders or mill stone: 
a. Horizontal grinders. (the top - runner type and the under - runner type)

b. Vertical grinders.

2. Roller mills which can be designed to produce both compression and attrition grinding.

The main objective of the present work is to develop a small locally made crushing unit and study some engineering factors affecting date pits crushing and evaluating the performance of crushing unit.

\section{MATERIALS AND METHODS}

The experiments were carried out at Faculty of Agricultural Engineering, Al-Azhar University, Nasr City during the years of 2013 - 2015 for small crushing machine locally manufactured.

\section{Date pits Variety.}

Experiments were carried out on date pits variety sewi. Some physical and mechanical properties of 100 date pits are studied according to (Khairy and Attalla 1995) and listed in table (1).

Table (1): Some physical and mechanical properties of date pits.

\begin{tabular}{lll}
\hline Parameters & mean & $\mathrm{CV}(\%)$ \\
\hline Moisture content db (\%) & 7.75 & 1.18 \\
Length "L" (mm) & 21.50 & 8.52 \\
Width "W" (mm) & 10.02 & 4.89 \\
Thickness "T" (mm) & 8.53 & 4.90 \\
Mass "m" $(\mathrm{g})$ & 1.33 & 14.94 \\
Real density " $\rho_{r}{ }^{\prime}\left(\mathrm{g} / \mathrm{cm}^{3}\right)$ & 1.27 & 4.67 \\
Bulk density " $\rho_{b} "\left(\mathrm{~g} / \mathrm{cm}^{3}\right)$ & 0.83 & 1.15 \\
Friction angle " $\alpha{ }^{o}\left(\mathrm{degree}^{3}\right)$ & 27.47 & 3.00 \\
Angle of repose " $\theta^{o}$ " ( degree) & 15.96 & 14.99 \\
Compression force $(\mathrm{kN})$ & 2.55 & 4.8 \\
Shear force $(\mathrm{kN})$ & 1.37 & 8.3 \\
\hline
\end{tabular}

\section{Crushing unit:}

The crushing unit installation used in this study is shown in Fig (1).

The frame was constructed of steel plate $(60 \times 60 \times 3) \mathrm{mm}$ to carry the 
engine and fixed it by means of four sets screw bolts and nuts. The frame also carried the crushing unit and the power transmission system.

The feeding hopper was installed to feed the date pits into the crushing unit. The gate of this hopper sloped gradually by $30^{\circ}$ to keep a free flow of date pits. The gate was drilled on the side of hopper to control on the feeding rate of date pits from hopper to crushing unit.

The crushing unit was necessary for crush the date pits to facilitate the crushing process. Cracking process is done by a pair of herringbone cylinders of $80 \mathrm{~mm}$ diameter and $290 \mathrm{~mm}$ length. The clearance between cylinders was adjusted by tow screws.

An electrical motor (1400 rpm, $1.5 \mathrm{~kW}$ ) was used to drive the crushing unit the power from the source was transmitted to crushing unit by means of pulley and $\mathrm{V}$ belt and sprocket wheels and chain.

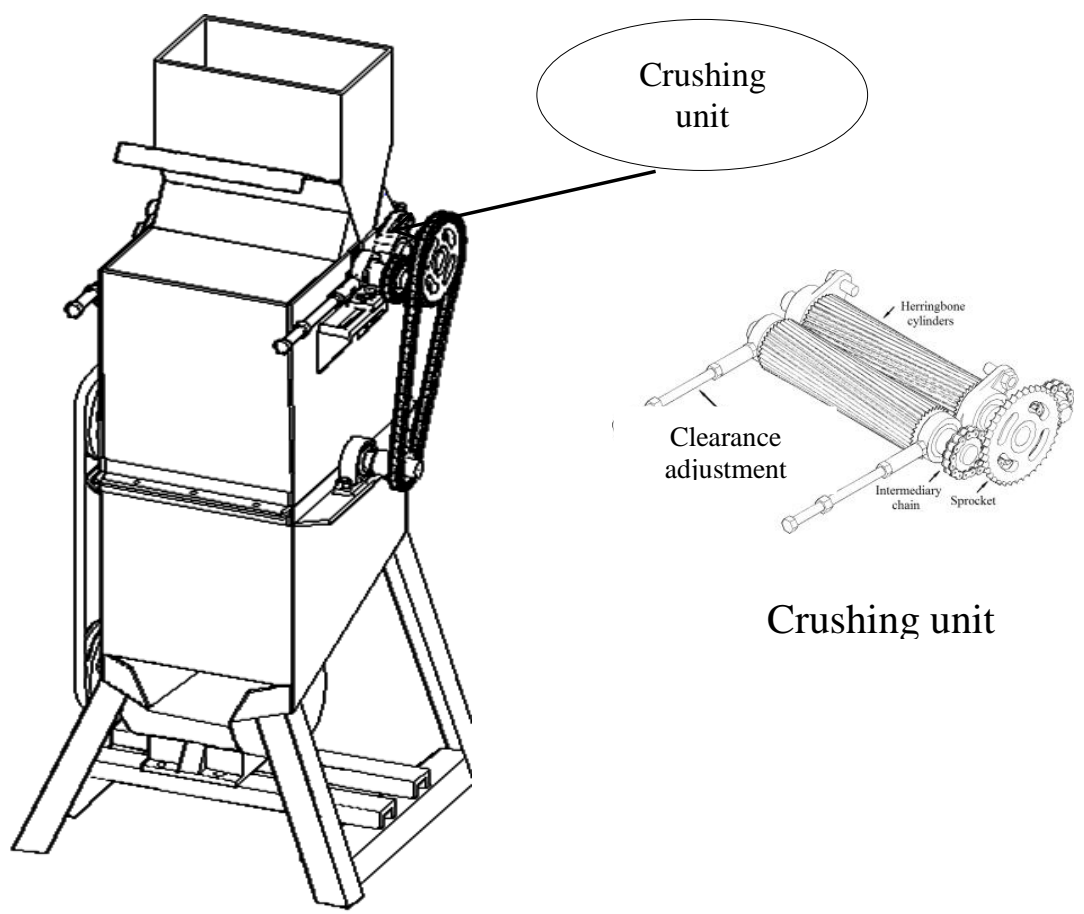

Fig. (1): Isometric of the developed crushing unit.

The effect of the following variables on the date pits particle size, crushing unit productivity and specific energy requirement for date pits were studied: 
1. Four cylinders speed of 150, 250, 350 and $450 \mathrm{rpm}$.

2. Three clearances between cylinders of zero, 1 and $2 \mathrm{~mm}$.

3. Three opening feed areas of $30,37.5$ and $45 \mathrm{~cm} 2$.

\section{Particle size distribution:}

The date pits mean particle size $(\mathrm{mm})$ was measured by using different sizes sieves "Ci" (mm) and weighting the weight over each sieves "Wi" (gm) where $\mathrm{i}$ is the sieve number and the following equation were used (Finch. 2009).

$$
L=\frac{(C 1 * W 1+C 2 * W 2+C 3 * W 3+\ldots . .+C n * W n)}{W 1+W 2+W 3+\ldots . .+W n}
$$

\section{Productivity:}

Crushing time of $1 \mathrm{~kg}$ of date pits was measured by means of a stopwatch to determine the machine productivity in $\mathrm{kg} / \mathrm{h}$.

$$
\text { Productivity }=\frac{\text { mass of crushed date pits }(\mathrm{kg})}{\text { Time of crushing }(\mathrm{h})}
$$

\section{Crushing power requirements:}

A digital AVO meter was used for measuring the current Amber before and during experiments the total consumed electric power under machine working load (kW) was calculated according (Lockwood and Denstan, 1971) by the following equation.

$$
\operatorname{power}(k W)=\frac{(I \cdot V \cdot \eta \cdot \cos \theta)}{1000}
$$

Where:

I : Current strength in Amperes.

$\mathrm{V}$ : Voltage strength (equal to220 V),

$\operatorname{Cos} \theta$ : Power factor (equal to 0.85 ) and

$\eta$ : Mechanical efficiency assumed to be (90\%)

\section{Specific energy requirement}

The specific energy requirement $(\mathrm{kW} . \mathrm{h} / \mathrm{Mg})$ was calculated by using the following equation:

$$
C E=\frac{\operatorname{Power}(k W)}{\text { produtivity }(M g / h)}
$$




\section{RESULTS AND DISCUSSION}

There are no results for the following operational conditions:

At zero mm clearance between cylinders and $450 \mathrm{rpm}$ for cylinders speed at all opening feed area $\left(30,37.5\right.$ and $\left.45 \mathrm{~cm}^{2}\right)$ and at the same clearance where the speed was $350 \mathrm{rpm}$ for $45 \mathrm{~cm}^{2}$ opening feed area. That is because of the high loud on the electric motor led to stop the crushing operation.

- Effect of cylinders speeds on date pits particle size:

Fig (2) illustrated the relationship between the cylinder speed "Cs" (rpm) and date pits mean particle size $(\mathrm{mm})$ at different opening feed areas and clearances between cylinders.

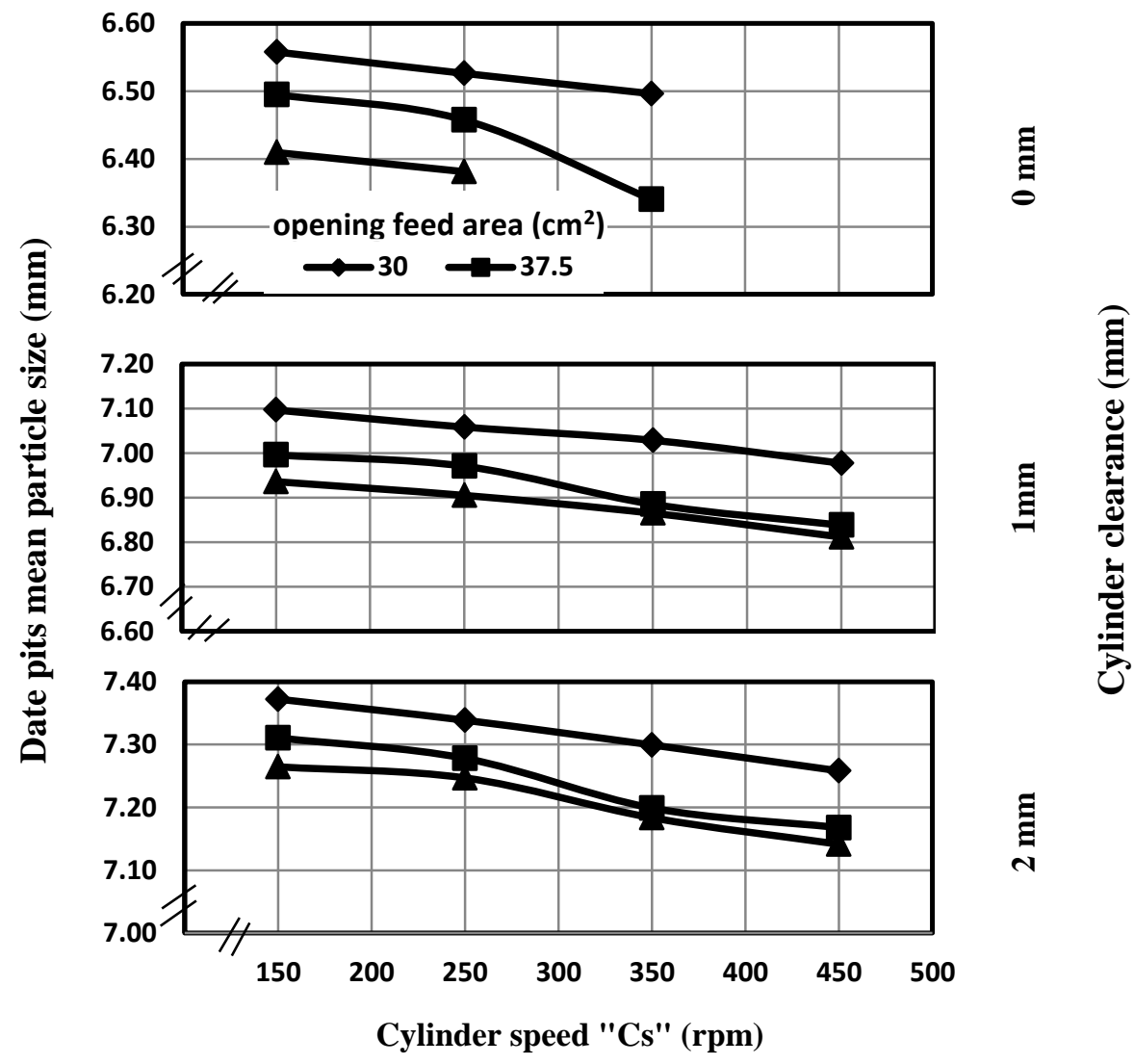

Fig (2): Date pits mean particle size (mm) Vs Cylinder speed "Cs" (rpm) at different opening feed areas and clearances between cylinders. 
The obtained data showed that the date pits mean particle size decreased with the increase of both opening feed area and cylinders speed and it increased with the increase of clearance between cylinders.

The minimum value of date pits mean particle size was $6.34 \mathrm{~mm}$ at opening feed area of $37.5 \mathrm{~cm}^{2}, 350 \mathrm{rpm}$ cylinders speed and $0 \mathrm{~mm}$ clearance between cylinders while the maximum value of date pits mean particle size was $7.37 \mathrm{~mm}$ at opening feed area of $30 \mathrm{~cm}^{2}, 150 \mathrm{rpm}$ cylinders speed and $2 \mathrm{~mm}$ clearance between cylinders.

- Effect of cylinders speeds on crushing unit productivity:

Fig (3) illustrated the relationship between crushing unit productivity "CPr" (kg/h) and cylinder speed "Cs" (rpm) at different opening feed areas and clearances between cylinders.

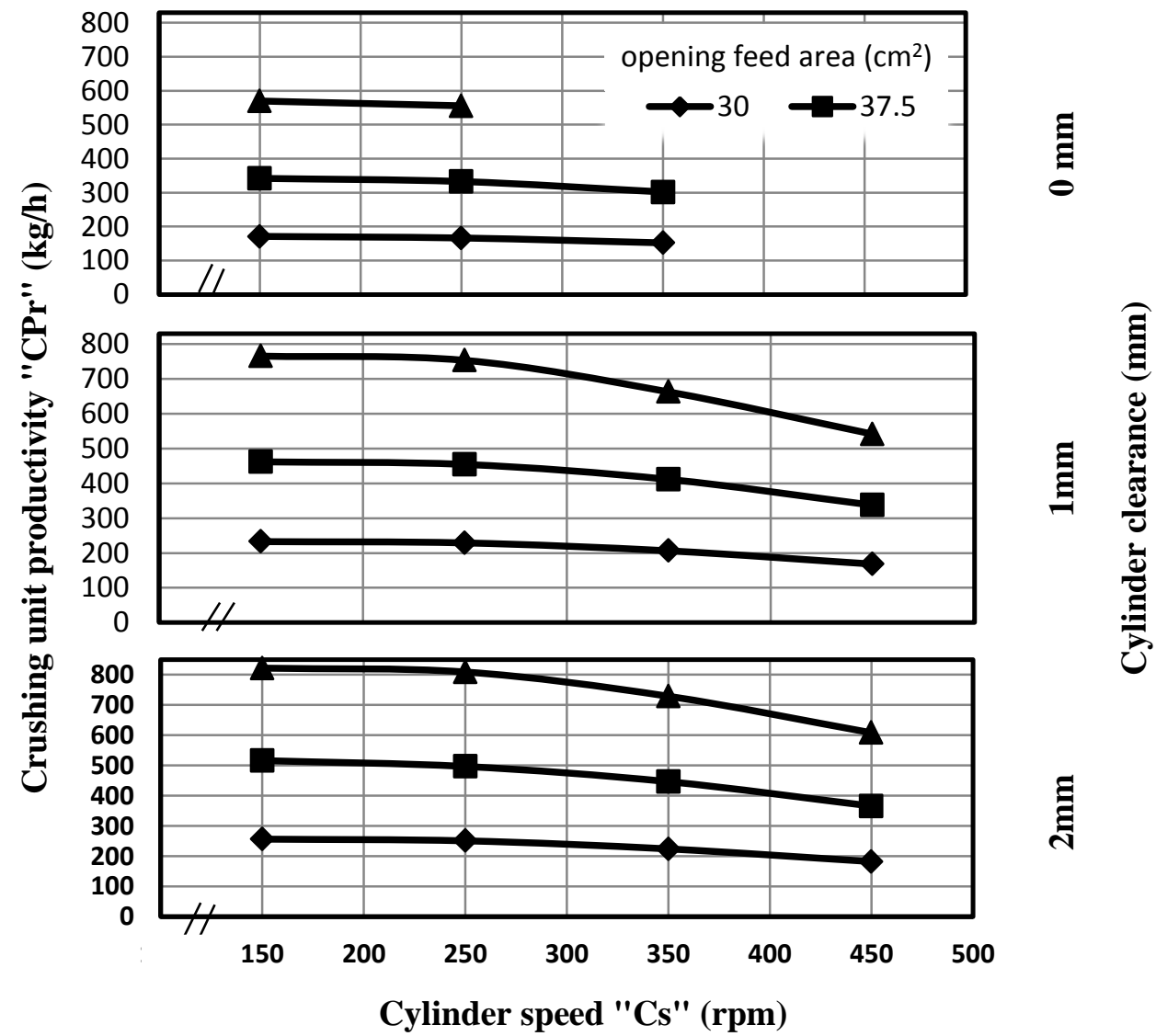

Fig (3): Crushing unit productivity "CPr" (kg/h) Vs Cylinder speed "Cs" rpm at different opening feed areas and clearances between cylinders. 
The obtained data showed that the crushing unit productivity increased with the increase of both opening feed area and clearance between cylinders and decreased with the increase of the cylinder speed.

The maximum value of the crusher unit productivity was $822 \mathrm{~kg} / \mathrm{h}$ at opening feed area of $45 \mathrm{~cm}^{2}, 150 \mathrm{rpm}$ cylinders speed and $2 \mathrm{~mm}$ clearance between cylinders; while the minimum value of the crusher unit productivity was $152 \mathrm{~kg} / \mathrm{h}$ at opening feed area $30 \mathrm{~cm}^{2}, 350 \mathrm{rpm}$ cylinders speed and $0 \mathrm{~mm}$ clearance between cylinders.

- Effect of cylinders speed on specific energy requirement for crushing unit:

Fig (3) illustrated the relationship between cylinders rotational speed "Cs" (rpm) and specific energy "CE" (kW.h/Mg) at different opening feed areas and clearances between cylinders.

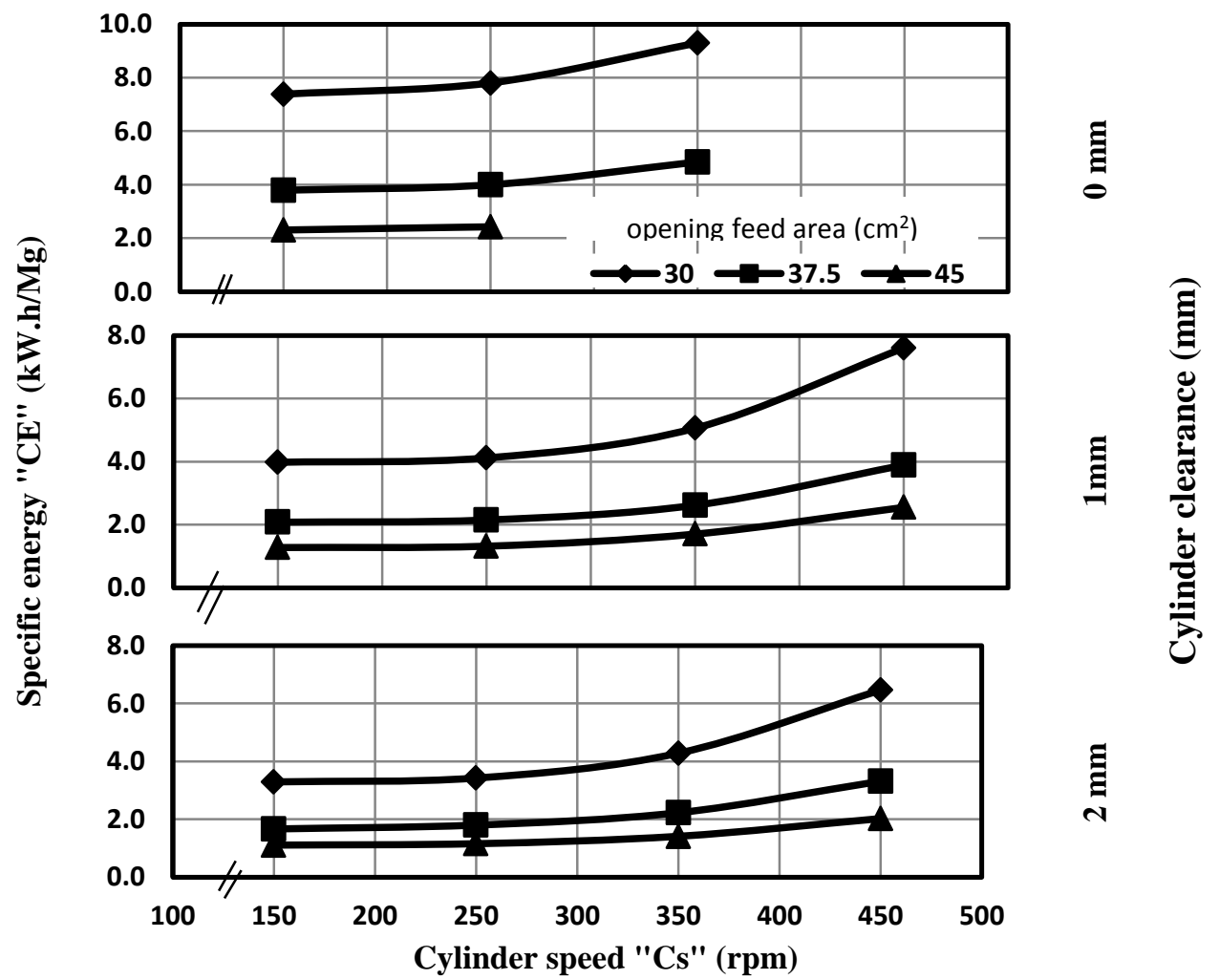

Fig (4): Crushing unit Specific energy "CE" (kW.h/Mg) Vs Cylinder speed "Cs" (rpm) at different opening feed areas and clearances between cylinders. 
The obtained data showed that the specific energy requirement decreased with the increase of both opening feed area and the clearance between cylinders and increased with the increase of cylinders speed. this results were agreement with werby et,al (2012).

The maximum value of Specific energy requirement was $9.30 \mathrm{~kW} . \mathrm{h} / \mathrm{Mg}$ at opening feed area of $30 \mathrm{~cm}^{2}, 350 \mathrm{rpm}$ cylinders speed and $0 \mathrm{~mm}$ clearance between cylinders; while the minimum value of specific energy requirement was $1.11 \mathrm{~kW} . \mathrm{h} / \mathrm{Mg}$ at opening feed area of $45 \mathrm{~cm}^{2}, 150 \mathrm{rpm}$ cylinders speed and $2 \mathrm{~mm}$ clearance between cylinders.

\section{CONCLUSION}

The minimum value of date pits particle size was $6.34 \mathrm{~mm}$ at opening feed area of $37.5 \mathrm{~cm}^{2}, 350 \mathrm{rpm}$ rotational speed and $0 \mathrm{~mm}$ clearance between cylinders while the maximum value of date pits particle size was $7.37 \mathrm{~mm}$ at opening feed area of $30 \mathrm{~cm}^{2}, 150 \mathrm{rpm}$ cylinders speed and 2 $\mathrm{mm}$ clearance between cylinders.

The maximum value of the crusher unit productivity was $822 \mathrm{~kg} / \mathrm{h}$ at opening feed area of $45 \mathrm{~cm}^{2}, 150 \mathrm{rpm}$ cylinders speed and $2 \mathrm{~mm}$ clearance between cylinders; while the minimum value of the crusher unit productivity was $152 \mathrm{~kg} / \mathrm{h}$ at opening feed area $30 \mathrm{~cm}^{2}, 350 \mathrm{rpm}$ cylinders speed and $0 \mathrm{~mm}$ clearance between cylinders.

The maximum value of Specific energy requirement was $9.30 \mathrm{~kW} . \mathrm{h} / \mathrm{Mg}$ at opening feed area of $30 \mathrm{~cm}^{2}, 350 \mathrm{rpm}$ cylinders speed and $0 \mathrm{~mm}$ clearance between cylinders; while the minimum value of specific energy requirement was $1.11 \mathrm{~kW} . \mathrm{h} / \mathrm{Mg}$ at opening feed area of $45 \mathrm{~cm}^{2}, 150 \mathrm{rpm}$ cylinders speed and $2 \mathrm{~mm}$ clearance between cylinders.

\section{REFRENCES}

Allam, S. M, M. A. Hanafy, I. A. Gomma and A. M. Abdou (1997). Effect of ammoniation on date seeds utilization on dairy ration. Egypt j nutration and feeds (special lssue): 201-210.

Almana, H. A; and R. M. Mahmoud (1994). Palm date seeds as an alternative source of dietary fibre in Saudi bread. Ecology of Food and Nutrition, 32: 261- 270. 
Bekheet, S (2013). Date palm biotechnology in Egypt. App. Sci. Report. 3(3): 144- 152.

El- Agamy S. Z, T. K. Mahdey. and O.A. Khalil (2003). Modification of some operation parameters for local manufactured hammer mill. $11^{\text {th }}$ Conf. of Misr Soc. Of Agric. Eng., Oct. 20: 830- 840.

FAO (2012). Fao statistical yearbook. Pp 137 <http; // faostat. Fao. org/ site/ 339 / default. Aspx>.

Finch, T. (2009). Incremental calculation of weighted mean and variance. University of Cambridge. < https: //scholar. google.com.eg/scholar? Incremental+calculation+of+weighted+mean+and+variance.+Uni versity+of + Cambridge \&btnG $=\& \mathrm{hl}=\mathrm{ar} \& \mathrm{as} \_\mathrm{sdt}=0 \% 2 \mathrm{C} 5>$

Khairy, M. F. A and A. M. Attalla (1995). Physical and mechanical properties of fruits of some date palm cultivars growing in Gassim region, Saudi Arabia. Misr J. Agric. Eng. 12 (3): 529-540.

Kozmin , P . A . ( 1988 ) Flour milling - Coerge Routledge of sons LTD - New yourk. D . Van Nostrand Company.

Lockwood, F. B and R. Dunstan (1971). Electrical engineering principle minimum. Educational books Ltd. London. (C.F Tayle et.al 2011)

Maynard , A . and J . L . Heid (1964). Food processing operations . Vol . 3 Westport connectiout . The Avi publishing company, Inc . pp ,200-217.

Simmons, N. O. (1963). Food milling and associated subject . London , Leonard Hill (Books) Limited.

Tayle, S. A, A. A. El Nakib, A. K. Zaalouk and A. N. Ahmed (2011). Development and evaluation of an cracking apricot stone machine. The $18^{\text {th }}$. Annual conference of the Misr Soc. Of Ag. Eng., 26-27 October 2011: 107-128.

Werby, R. A, A. K. Zaalouk and S.H. Desoky (2012). Effect of some operating factors on the efficiency of sweet lupine Seeds milling Spruce. Misr J. Agric. Eng. 29 (4): 215- 229. 


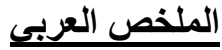

\section{بعض العوامل الهندية المؤثرة علي جرش نوى التمر}

\section{محمد فايد عبا الفتاح خيري" سمير حافظ محمد دسوقي*** رأفت علي أحمد وربي"** خالا عابدين موسي علي ***}

تعتبر جمهورية مصر العربية من أكثر الدول إنتاجا للبلح في العالم حيث بلغت إنتاجيتها من

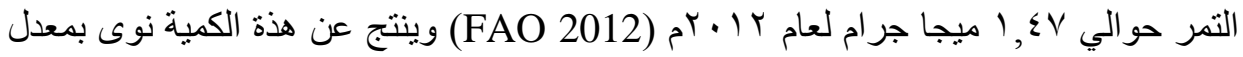
• 10 ـ 10 من الإنتاج. وعدم تو افر نوى التمر في صورة مجروشة أو مطحونة أدى الي عدم استخدامه في العديد من الصناعات القائمة على هذا المنتج الثانوي وذللك بسبب صنوي صعوبة طحنه الإنه لاحتو ائه علي نسبة عالية من السيليلوز بالإضـافة إلي عدم تو افر آلات متخصصة في جرش نوى ونى

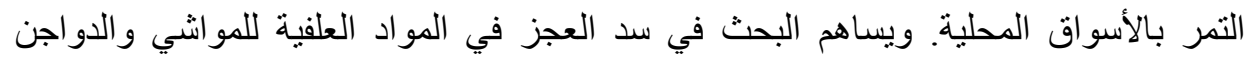

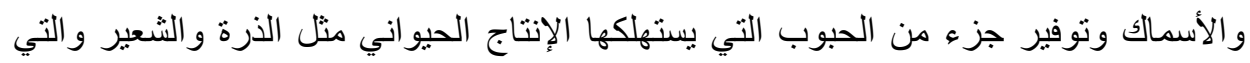

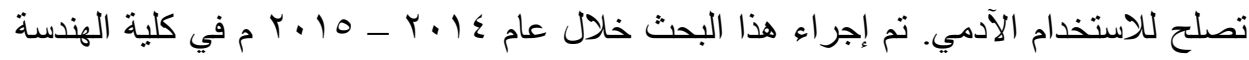
الزر اعية جامعة الأز هر الأنر ويهدف هذا البحث إلي الاستفادة من نوى التمر عن طريق جرشه حيث تم در اسة بعض العو امل الهندسية المؤثرة علي جرش نوى التمر وتصنيع آلة محلية الصنع رخيصة الثمن يمكن للمز ارع المصري اقتنائها. وللوصول إلي هذا الهدف تم دراسة الأتي:

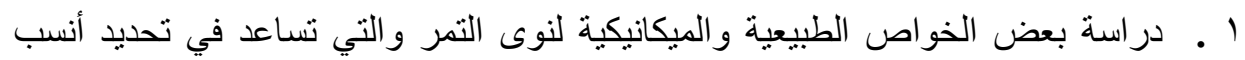
تصمبم للآلة. r • تصنيع آلة محلية لجرش نوى التمر تناسب الكميات الصغيرة وذات تكاليف اقتصادية بسيطة وسهلة الصبانة.

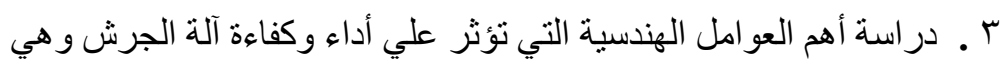

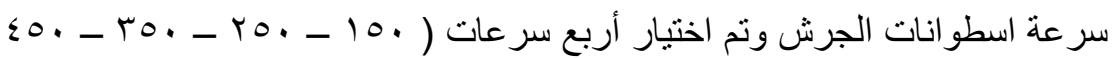

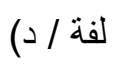

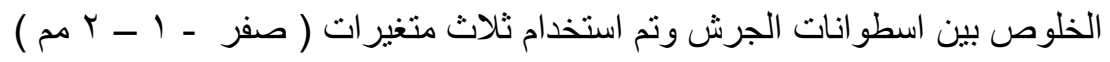

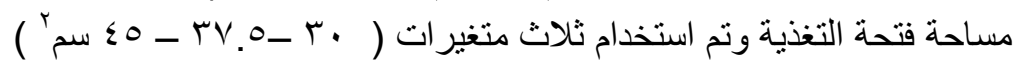

* أستاذ القوى و الآلآت الزر اعية المتفرغ - كلية الهندسة الزر اعية - جامعة الأزهر ـ القاهرة ** أستاذ مساعد- قسم هندسة القوى و الآت الزر اعية ـ ـ كلية الهندسة الزر اعية - جامعة الأزهر هره **** معيد ـ قمم هندسة القوى و الآت الزر اعية ـ كلية الهندسة الزر اعية ـ جامعة الأزهر. 


$$
\text { وكانت أهم النتائج: }
$$

1 ـ إنتاجية الجرش تنخفض بزيادة سرعة اسطو انات الجرش لكل الخلوصات بين الأسطو انات وتزداد مع زيادة الخلوص بين الأسطو انات كما تز اد بزيادة فتحات التغذية وكانت اكبر إنتاجية

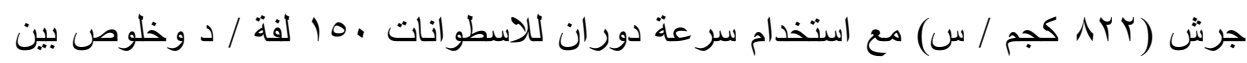

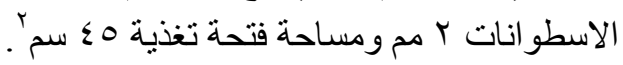

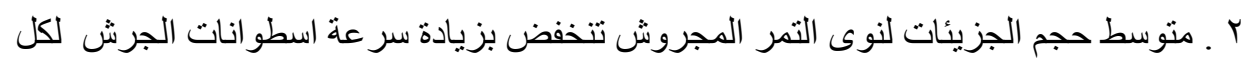
الخلوصات بين الأسطوانات، وتزداد مع زيادة الخلوص بين الأسطوانات مع كل سرعات

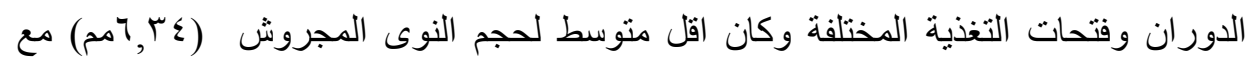
استخدام سر عة دوران للإسطو انات . هب لفة / د وخلوص بين الإسطو انات صفر مم ومساحة

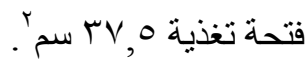
r. الطاقة النوعية المطلوبة للجرش نزداد بزيادة سرعة اسطوانات الجرش ل لكل الخلوصسات

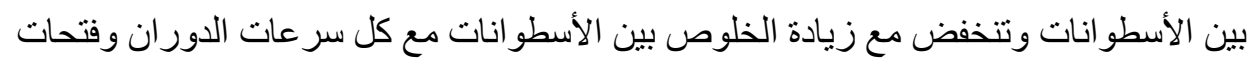
التغذية المختلفة وكانت اقل طاقة نوعية مطلوبة (1, 1, كيلو وات ـ س / كجم) مع استخدام

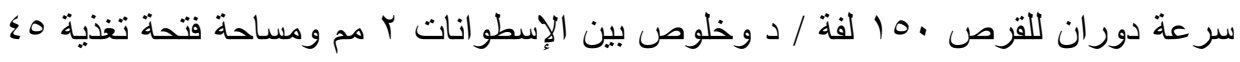

